\title{
Nanomole per Liter per Microgram per Kilogram per Day
}

National Cancer Institute

\section{Source}

National Cancer Institute. Nanomole per Liter per Microgram per Kilogram per Day. NCI

Thesaurus. Code C119464.

A unit of concentration equal to nanomoles per liter, divided by micrograms per kilogram per day. 